ユーザの労働内容や医療思想が十分考虑され製作される ことが少ないといえる，われわれが，日々どのような点 に思いをめぐらしているのか，そのうちからいくつか改 良をくわえて来たことを報告する。

\section{ZONARC の軌道管理用ファントムの試作}

千葉県救急医療センター放射線科

○高柳秀隆・佐藤律夫・鈴木広次

〔目的〕ZONARCの軌道チェック・ファントムを自 作し，断層軌道面および断層厚をチェックすると同時に， そのデータに基づいて軌道管理用ファントムを試作した ので報告する。

〔結果考察〕 (1)高い精度で実際の軌道・断層厚を知る ことにより，撮影時の基準線の設定等がマニュアル・ブ ックによるよりも合理的になった。(2)軌道の狂い等に対 する簡便なスクリーニング・ファントムとしては勿論の こと, 調整後のチェック・ファントムとしても有用であ る. (3)経年的な精度管理ファントムとして, 簡便にかつ, 再現性よく使用可能と考える。

\section{座長集約}

両面乳房撮影システムの小览胸部撮影への応用では， 更に検討が必要としている。小児気道撮影用補償増感紙 とフィルタ法の比較であるが, 感度および鮮鋭度などが 向上して扔り有用と考える. 上部消化管検查でフィルム を 7 枚に限定して撮影部位と体位を検討している。

質問 長野(岡田) 窮窟部領域の早期癌の見逃しが問 題となっている，穹蕯部の撮影が数少ないのではないか.

答 半立位第 2 斜位と立位第 1 斜位で下部食道ととも に入れている，見逃し例については充分検討してゆく. 消化管検查機材の改造であるが, 患者の安全と検査の能 率化また装置の管理はX線装置全般についても言えるこ とであろう.ファントムによる zonarcの管理は撮影軌 道の基礎的データが得られることで撮影精度の向上が計 れ有効な手段である。

\section{CT・カメラ等}

座長 荒井 一 (東京女子医科大学病院)

\section{TAE 前後における Dynamic CT の試み}

東邦大学附属大森病院中央放射線部

○山内 策・町田啓一・菊地英夫

肝細胞癌 (HCC) に対して Transcatheter arterial embolization (TAE) が有力な非手術的治療として広く 行われているが，その効果判定のためのDynamic CT の 方法, 意義について検討した. Time Density-Curve (TDC)によると急激な CT 值の上昇のみられる $\mathrm{HCC} の$ 部分はTAE後血流が遮断されたことが容易に確認でき
た。またTDCのPeakの高さの mapping (PHmapping）により血流の遮断されたようすを視覚的にとらえ ることができた。TAEの予後の観察にDynamic CT は 簡便で有効な方法であると思われる。

16. 耳下腺部腫济の SialoCT 撮影について

千葉大学医学部附属病院放射線部

○渡道和洋・梁川範幸・花沢保司

菊池孝二・渡辺 浩・大石英二

酒井尚信・植松貞夫

従来, 耳下腺部腫瘍の検査方法は種々あるが, X線 CT の性能の向上に伴い，空間分解能に優れたCT画像 (Target 画像) が得られるようになった．当大学では正 確な情報を得るためにSialography後にSialo CT (Target)を実施している.そこでわれわれはこのCT 撮 影の諸条件とCT 画像の信頼性を確認するために Phantom を試作撮影し，その画像の持っている情報を最 大限に表現しようと試み，臨床面への応用についても検 討した。術前検查として伸展範囲・良性・悪性腫瘍の区 別，顔面神経の位置関係の予測等の診断情報を提供する ことは重要であり，CT 画像（Target）とその再構成画 像は，臨床上極めて有用であった。

\section{7. 側頭骨 CT の検討}

埼玉医科大学総合医療センター

○大野克美・小川 清・宮野良介 篠崎敏雄

〔目的〕高分解能 CT を側頭骨領域においてルーチン 検査として行う施設が増加している。そこで今回われわ れは側頭骨 CT 画像を把握すべく検討を加え, 若干の知 検を得たので報告する。

[方法]

1) Coronal と Transvers image の比較

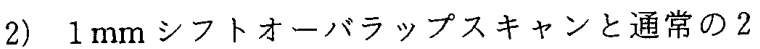
$\mathrm{mm}$ スライスとの比較

〔考察〕側頭骨の内部構造は contrast の強い部分で あるため，スライス厚の影響を強く受け，耳小骨や螖牛 などの詳細な部分では $1 \mathrm{~mm}$ shift overlap scan が有用 であり，また，側頭骨 CT は 2 方向撮影が有用であった。

18. $\mathrm{CaCO}_{3}$ による吸収係数と CT 值の直線性について

昭和大学病院中央放射線部

○川末健作・新田 勝・小田正記 埼玉県立小児医療センター 前野俊和・神田幸助・松田幸広 帝京大学病院中央放射線部 川村 守 